\title{
Five Things Family Businesses are Reckoning With Now
}

\author{
Mat Hughes (Loughborough University) \\ Alfredo De Massis (Free University of Bozen-Bolzano)
}

KEYWORDS: Strategy, Family Business, Succession, crisis management.

Family businesses everywhere are responding to Covid-19 in profound ways, balancing the need to preserve cherished family traditions and social capital against the mandate to control costs at a time of economic peril. In this video, also available here as a podcast, professors Mat Hughes and Alfredo De Massis talk about how the pandemic is forcing reckonings in five realms -- including succession, internal and external relationships, financial health versus social health, longterm orientation versus the need to adapt, and balancing future wealth against the need for more liquidity. De Massis also shares insights from his study of a resilient family that weathered four different catastrophes and emerged stronger from each one.

Link to video

Professor Mat Hughes (https://soundcloud.com/user-49751720) · Covid-19 Challenges for Family Businesses and Capitalizing on Resilience (https://soundcloud.com/user-49751720/covid-19-challe nges-for-family-businesses-and-capitalizing-on-

resilience) 